\title{
The Challenge of Differing Perspectives Surrounding Grades in the Assessment Education of Pre-Service Teachers
}

Jennifer Mitton-Kukner, Elizabeth Munroe, and Deborah Graham St. Francis Xavier University

\begin{abstract}
In this paper we describe the challenges we experience teaching an assessment course to pre-service teachers, as part of their studies in a bachelor of education program. As we teach the course, our intent is to explicitly model assessment practices that reflect a philosophy of success for all, rather than sort and rank. Rather than ranking students by achievement, our goal is to model how to tap into the learning potential of every student (Stiggins, 2005). Inquiring into moments that show how the teaching of a success for all philosophy is tension-filled in teacher education, we demonstrate the multiple and conflicting perspectives informing grades. We situate our discussion in the area of assessment in higher education and propose a series of actions, which may resonate with instructors in teacher education and higher education contexts.
\end{abstract}

\section{Résumé}

Cet article décrit les défis rencontrés lors de l'enseignement d'un cours d'évaluation pour defuturs enseignants étudiant au baccalauréat en éducation. Durant le cours, notre intention était de modéliser explicitement les pratiques d'évaluation qui reflètent une philosophie de la réussite pour tous, plutôt que celle du tri et du classement. Ainsi, au lieu de classer les élèves par rapport à leur réalisation, notre objectif était de modéliser la façon de puiser dans le potentiel d'apprentissage de chaque élève (Stiggins, 2005). En enquêtant sur des moments qui montrent à quel point l'enseignement d'une philosophie de réussite pour tous est rempli de tension dans la formation des enseignants, nous démontrons les perspectives multiples et contradictoires que représente le fait de remettre les notes. Nous situons notre discussion dans le domaine 
de l'évaluation en enseignement supérieur et proposons une série d'actions qui peuvent trouver un écho chez les instructeurs des enseignants et dans des contextes d'enseignement supérieur.

As he looked into my eyes, he stated quite assertively, "Come on, Deb, the grade does matter." He went on to tell me that he had aspirations for further study and that achieving an 85 percent average was paramount to his success.

-Moment 1, October 1, 2012

In this paper, we discuss our experiences teaching assessment courses to pre-service teachers as part of their program of studies for a bachelor of education degree. The above excerpt illustrates one student's view of grades as a means of advancement. We explain how this preoccupation with getting good grades over learning course content exemplifies an ongoing tension informing our teaching and student learning. We identify the issues that arise as we explicitly model a philosophy of success for all in a higher education context shaped by a traditional understanding of sort and rank (Stiggins, 2005).

Stiggins (2005) argues that assessment may be used to help students achieve learning success and describes the notion of sort and rank as representing a traditional understanding of assessment fostered by fixed grades, where students are spread along an "achievement continuum" (p. 324) representing their rank upon graduation. Stiggins suggests this systematic condition feeds into "the implicit mission of schools: the greater the spread of achievement among students, the more it reinforced the rank order" (p. 325). Today's standards-based education, Stiggins further suggests, has changed the context of schools, in that it is expected that all students will achieve a certain minimum level of achievement in their learning, an expectation that has profound implications for the role of assessment: it "must now be revised to permit the possibility that all students could succeed at some appropriate level" (p. 326). As part of this new mission for schools, formative assessment practices are encouraged, with an emphasis upon "assessment for learning," where ongoing assessment methods provide students, teachers, and parents with a "stream of evidence" (p. 327) as students progress to learning knowledge and skills that inform established standards. As teacher educators preparing pre-service teachers for the contexts of schools, we are mindful of how the students we teach must be pedagogically competent in their understanding and application of assessment as a philosophy and approach that fosters and documents ongoing student learning.

Our two-year bachelor of education (BEd) program is located in rural eastern Canada. Our pre-service teachers have already completed at least one degree before entering the program. In each year of the program, there are approximately 115 pre-service teachers. In the fall semester of their second year they are required to take a three-credit, 36-hour course in classroom assessment and evaluation. There are three sections of the course, for elementary, middle school, and high school pre-service teachers, and approximately 40 pre-service teachers are enrolled in each section. The majority of our students are between the ages of 23 and 28 and are from the Atlantic Canadian region as well as other provinces in Canada, particularly Ontario and Alberta. 
Despite the 20 years of educational reform across Canada and the world to advance student-centred learning and supportive assessment practices (Alberta Assessment Consortium, 2012; Black \& Wiliam, 1998; Wiliam, 2011), the majority of our students arrive with traditional understandings of assessment: most view assessment as a summative event that occurs at the end of the learning cycle as opposed to a process of formatively informing student learning and teacher instructional practices throughout. Many of our pre-service teachers acknowledge their high school and undergraduate education as having a significant impact upon their understanding of assessment in terms of traditional summative methods.

In our work with pre-service teachers, we explicitly model a variety of supportive assessment strategies (Chappuis, 2009; Roscoe, 2013) that have been linked to student success (Black and Wiliam, 1998). We believe these strategies are important to enhance the learning of our university students, but we have an additional rationale for implementing them, in that we are preparing our students to teach in school contexts across Canada that include these assessment strategies in their education policies (Assessment for Learning in Canada (http://caflnforum.ca/resources/); Poth, 2013). We understand that before their arrival in our program many pre-service teachers may not have had the opportunity, as students, to experience the success for all philosophy underlying current assessment, in that "today's adults grew up in schools designed to sort us into the various segments of our social and economic system" (Stiggins, 2005, p. 324). We believe that explicit modelling of strategies as suggested by Swennen, Lunenberg, and Korthagen (2008) is crucial in our teaching of pre-service teachers, but we experience continued challenges as we work to help our students shift their assessment philosophy, developed through their 17year apprenticeship of observation (Lortie, 2002) in schools. In particular, the timing and strategies surrounding the determination of grades and the underlying meaning of grades raise perplexing issues.

In what follows, we pinpoint particular moments that represent recurring challenges in teaching pre-service teachers about assessment. We name the bumping points that indicate constraints shaping the context in which we teach, such as the prior assessment experiences of our students and how these inform their understanding of our teaching and assessment practices. Finally, we discuss theoretical implications and propose a series of actions in response to the challenges that we must navigate. We feel our suggestions may resonate with instructors in teacher education and higher education contexts and show possible ways of proceeding pedagogically to allow students to experience opportunities for learning and success in response to supportive assessment practices. Our challenge in using assessment to foster student learning is not a situation particular to teacher education; instructors of higher education are increasingly being asked to implement such practices in their teaching so as to create better teaching and learning environments (Altbach, Reisberg, \& Rumbley, 2009; McKinney, 2007; Norton, 2009). Our paper provides a window into the complexity of doing so.

\section{Teaching About Success for All in a Sort and Rank Context}

Teaching assessment courses to elementary, middle school, and secondary pre-service teachers with the intent to explicitly model an inclusive practice of success for all is challenging within our teaching context. As educators in an institution of higher learning that 
promotes ranking or “summing up one's judgment of a performance or person into a single holistic number or score" (Elbow, 1993, p. 187), we struggle to promote a philosophy of success that surpasses "a single scale or continuum or dimension along which all performances are hung” (p. 187). In a previous article (Munroe et al., 2012), we described how we implement a variety of assessment strategies in the teaching of assessment to pre-service teachers; some of which include: aligning course outcomes to course assessment and evaluation, separating academic achievement of outcomes from non- academic elements, collaboratively creating achievement indicators for course outcomes, co-constructing criteria with students for assignments, setting up opportunities for peer feedback before an assignment is submitted, and administering and marking a test according to supportive, research-suggested strategies. Our past and current practices reflect what Stiggins (2005) refers to as a new mission for schools in that "they are to be places where all students become competent, where all students meet pre-specified standards and so are not left behind" (p. 324). We realize that failure to learn certain basic skills in school reduces people's ability to "survive in, let alone contribute to, an increasingly technically complex and ethnically diverse culture" (Stiggins, 2005, p. 326). Thus, teachers and schools have taken more responsibility, ensuring that all students achieve a certain level of achievement. Stiggins (2005) suggested that this change in the mission of schools has "profound" implications; working toward success for all in school contexts relies upon not only a shift in philosophy but also procedures to support such a shift, and this shift needs to start in teacher education programs (Stiggins, 1999). Currently, teachers in Canadian schools need to "think about assessment as a process that supports and enhances student learning" (McMillan, Hellsten, \& Klinger, 2011, p. 2). This mindset is critical for our pre-service teachers, who must enter schools prepared to promote this philosophy of assessment through their actions.

Stiggins's ideas are not limited to the United States. Assessment practices and policies in school contexts across Canada (Alberta Assessment Consortium, 2012; Manitoba Education, Citizenship \& Youth, 2006; Nova Scotia, 2012) and the world (Absolum, Flockton, Hattie, Hipkins, \& Reid, 2009; Cooper \& Cowie, 2010; Mansell, James, \& the Assessment Reform Group, 2009; Wiliam, 2011) are reflecting profound changes in how assessment has moved "from a culture of testing to a culture of learning" (Poth, 2013, p. 634). This shift acknowledges the importance of ongoing assessment: it may inform teachers' instructional decisions and actions as well as students' understanding of their learning. Higher education has also been influenced by changes in how assessment is viewed in schools, particularly in response to demands being placed upon universities for improved teaching and learning (Altbach et al., 2009; McKinney, 2007; Norton, 2009) and the role that assessment may play in formatively influencing student learning (Hatzipanagos \& Rochon, 2010; Irons, 2008; Sadler, 2010). However, the Canadian scholar Keith Roscoe (2013) notes, "Little attention appears to have been paid in the literature to improving formative or summative assessment in Canadian universities" (p. 1). As teacher educators, we note the complexity of educating pre-service teachers about current assessment practices that emphasize learning over testing (DeLuca \& Klinger, 2010; Poth, 2013) within a higher education context that is still, in many ways, shaped by traditional assessment approaches. One of the ways in which we are able to observe the complexity of this issue is through the differing perspectives of ourselves and our students on grades in the assessment education of pre-service teachers. 


\section{Mixed Messages: Grades and Their Importance in Different Contexts}

Throughout schooling, students are accustomed to teachers grading their work, and they learn to rely on that external judgment as confirmation of their intelligence and achievement (Dweck, 2006; Wiliam \& Reay, 1999). Kohn (1999) suggested that grades reduce students' interest in learning, their preference for challenging tasks, and the quality of their thinking. Kelsey (2006) found that graduate students who were enrolled in a grade-neutral course (that is, they were assured an $\mathrm{A}$ in the course regardless of their actions) read less of the assigned text, completed fewer assignments, and attended fewer classes. Kelsey concluded, "More than one grade-neutral course experience is required to change the well-established habits of extrinsically motivated students" (p. 30). In short, for many students, grades matter. Informing the meaning of grades, however, are multiple possibilities; some of these, we suggest, are affirmed by the sort and rank philosophy informing the educational contexts in which they learn (Klinger, DeLuca, \& Miller, 2008; Volante, 2006a).

Grades also matter to universities and colleges, affecting admission decisions at both the undergraduate and graduate levels. Grades are the primary basis upon which scholarship awards are decided. Grades may be related to students' confidence in applying for various university programs (Mullen, Goyette, \& Soares, 2003). Although our pre-service teachers' grades may not be the primary factor in being hired for a teaching position, school districts do request university transcripts, thus giving a strong message to prospective teachers that grades do matter.

Grades matter to us, as teachers, as well. We believe that our students' grades indicate the extent to which they have learned what we have tried to teach them. We are committed to maintaining high standards and to reducing the inflation of grades by not awarding marks for nonacademic factors such as class participation. We are also dedicated to ensuring that students' grades are not negatively skewed by unrelated work habits (such as handing in work late). Grade inflation and deflation have reduced confidence in the significance of a grade as an indication of learning (Vickers, 2000). Research has shown that admissions officers tend to favour applicants with higher grades, as indicative of their ability rather than the ease with which grades were achieved, not taking into account structural and situational factors informing applicant achievement (Swift, Moore, Sharek, \& Gino, 2013). This kind of practice has led to additional entrance tests or tasks being used as part of some university admissions and employment recruitment processes (Mellanby, Cortina-Borja, \& Stein, 2009; Rhodes, 2012).

It is clear that grades do matter-to students, to teachers, to educational institutions, and to employers. There is considerable complexity, however, in what exactly a grade represents, how a grade is determined, and the optimal timing of awarding a grade for student work. This is the broader context from which many of our pre-service teachers arrive and which we find ourselves directly bumping against in the teaching of assessment. Some of the strategies we explicitly model, which we explore in more detail later in the paper, specifically relate to students' grades. When we initially offer descriptive feedback and delay assigning grades on student work while strictly adhering to the idea that a grade must not be influenced by student work habits, or carefully support assessment events (such as quizzes) so that students experience success, our students are unsettled, compla- 
cent, confused, or sometimes resentful. The words and actions of some of our students point to their focus being on the grade and perhaps not on the learning. Initially we were dismayed by the students' strong emphasis on grades, but upon reflection and inquiry, we realized that grades not only matter to the pre-service teachers we teach, grades also matter to us, although our perspectives on their meaning often differ widely.

\section{Pre-Service Teachers and Assessment Education}

As part of our self-study, we turned to the established literature about pre-service teacher education and assessment. There is little consensus about best practices in the assessment education of pre-service teachers; scholars advocate for further research to better understand the development of pre-service teachers' assessment literacy (DeLuca \& Klinger, 2010; DeLuca, Chavez, \& Cao, 2013; Poth, 2013). Presently, the overall picture depicting the assessment education of pre-service teachers is less than hopeful. Scholars note that despite the inclusion of assessment courses in pre-service teacher education programs, these courses had little influence upon pre-service teachers' knowledge and pedagogy (Darling-Hammond \& Bransford, 2005; MacLellan 2004; Mertler, 2009). Pre-service teachers are largely portrayed as having little understanding of assessment principles and their relationship with effective instructional and assessment practices (Campbell \& Evans, 2000; Graham, 2005; Volante \& Fazio, 2007; Wang, Kao, \& Lin, 2010). For example, Volante and Fazio (2007) surveyed pre-service teachers in each of the four years of a teacher education program and found that their levels of self-efficacy regarding assessment were relatively low, with most participants placing emphasis upon summative purposes for assessment. In an examination of 57 course outlines of assessment courses from western Canadian teacher education programs, Poth (2013) found that while two-thirds of the programs supported the idea that assessment was to encompass a focus on student learning, there was "little recognition that assessment could be used to enhance instruction" (p. 645). In slight contrast, DeLuca and Klinger (2010) found that while pre-service teachers' confidence with assessment grew as they approached the end of their studies, their confidence was largely found to be connected to traditional, summative assessments as opposed to formative assessment tasks connected to ongoing student learning.

In order to foster assessment literacy among pre-service teachers (Popham, 2011), scholars have suggested the following pedagogical actions. Much emphasis is placed upon inquiry into pre-service teachers' conceptions of assessment (Graham, 2005; Wang et al., 2010; Volante \& Fazio, 2007); the importance of modelling a range of current instruction$\mathrm{al}$ and assessment strategies that pre-service teachers will need as they move into the field (DeLuca et al., 2013; Moss, 2003; Poth, 2013; Roscoe, 2013) the significance of experienced teachers working alongside pre-service teachers during their field experience (Graham, 2005; Wang et al., 2010; Volante \& Fazio, 2007); and the inclusion of pre-service teachers in the development of assessment criteria as part of coursework (Roscoe, 2013).

While our primary focus in this review of the literature is upon what is known about the assessment education of pre-service teachers, it also important to acknowledge what is known about in-service teachers in relation to their assessment practices, particularly as pre-service teachers work closely with in-service teachers during field placements. Because classroom assessment is complex in how it is informed by different purposes and communicated to different audiences, scholars have found that classroom assessment is 
challenging for teachers: its purposes may support, compete, and conflict with one another (Brookhart, 2003; Earl, 2013; Volante \& Beckett, 2011; Volante, 2010). Part of the complexity of classroom assessment in Canada is shaped by an increasing use of standardized, large-scale assessment (Ercikan \& Barclay-McKeown, 2007; Klinger, DeLuca, \& Miller, 2008). For example, Duncan and Noonan (2007) found that while experienced teachers used criterion-referenced rubrics, these were paradoxically informed by their understanding of norm-referenced judgments regarding assessment and grading practices. Remesal (2011) also found that many of the experienced teacher participants in her study were informed by diverse and sometimes dissimilar beliefs concerning the role of assessment in their teaching. Other scholars have found that targeted professional development promotes the development of in-service teachers' assessment knowledge (Gunn \& Hollingsworth, 2013; Wilson, 2008) and that teachers are becoming more acquainted with a range of assessment practices (Volante \& Beckett, 2011). Our review of this body of work enabled us to better understand some of the contextual complexities that we experience as teacher educators and to anticipate some of the challenges that pre-service teachers may experience as they enter into the field. However, we note the lack of literature describing the pedagogical challenges of teaching pre-service teachers and having them experience "new" assessment strategies, with the exception of studies conducted by Roscoe (2013) and Hudson-Ross and Graham (2000).

Roscoe (2013) describes an innovative joint undertaking between the University of Lethbridge and the Alberta Assessment Consortium in which teacher educator participants took part in a series of assessment workshops that employed research-based assessment practices to enhance the assessment education of pre-service teachers and to better prepare them for teaching in K-12 school settings. Roscoe emphasized that despite the success documented in this study in terms of participant learning,

students' [pre-service teachers'] previous experience with, and predispositions towards assessment may form a barrier to implementation...[and that] University students may be accustomed to a passive role in the classroom and motivated by grades, rather than being focused on learning and eager to take a more active role in their own assessment. (p. 13)

Like Roscoe (2013), Hudson-Ross and Graham (2000) argue that teacher educators should be models of good teaching; within the role framework they propose, they include the role of "assessor in a constructivist classroom." As part of that approach, they suggest that "pushing grades to the background so that learning can occur is probably one of the most difficult but important constructivist moves" (p. 17). We read their work and Roscoe's (2013) work with interest and agreed with what was proposed, as it is something we also do in our own teaching; but we also noted the lack of description of the difficulty of teaching pre-service teachers using supportive assessment practices and the challenge of positioning grades in the background. For example, when we try to push grades to the background (as part of a success for all philosophy versus sort and rank), we encounter resistance from students because grades seem to matter, as reflected in our opening excerpt. 


\section{Theoretical Framework}

In the fall of 2012 we began to explore our experiences as instructors of assessment courses through ongoing regular discussion and noted the challenge of modelling new assessment strategies in our work with pre-service teachers (Poth, 2013; Volante, 2006b). Research suggests that in order for pre-service teachers to internalize new assessment practices, teacher educators need to explicitly model such practices (Swennen et al., 2008), as well as link such practices with theory (Lunenberg, Korthagen, \& Swennen, 2007). White (2011), however, suggests that modelling of a practice by teacher educators does not imply buy-in and/or transfer to future teaching. In response to what White suggests, we feel that in addition to modelling, pre-service teachers should also experience a success for all philosophy as part of their assessment education so as to better enact such practices during their practicum teaching placements and, indeed, later on when they enter classrooms as full-time professionals (Russell \& Bullock, 2010). In order to make clear our understanding of a success for all philosophy and how it informs our instructional and assessment practices, we provide a table below with an overview of strategies associated with each philosophy.

\begin{tabular}{|l|l|}
\hline $\begin{array}{l}\text { Strategies Informed by a Success For } \\
\text { All Philosophy }\end{array}$ & $\begin{array}{l}\text { Strategies Informed by a Sort and } \\
\text { Rank Philosophy }\end{array}$ \\
\hline $\begin{array}{l}\text { Descriptive feedback with opportunities to } \\
\text { improve assignments. }\end{array}$ & $\begin{array}{l}\text { All assignments are marked as summative } \\
\text { grades. }\end{array}$ \\
\hline $\begin{array}{l}\text { Course outcomes are discussed and presented } \\
\text { in accessible language and in connection to } \\
\text { clear assignment criteria. }\end{array}$ & $\begin{array}{l}\text { Course outcomes and related assignment } \\
\text { criteria are assumed to be understood. }\end{array}$ \\
\hline $\begin{array}{l}\text { Clear criteria for assignments, given in } \\
\text { advance to students, and closely adhered } \\
\text { to when feedback is provided throughout } \\
\text { the course and when final assignments are } \\
\text { marked. }\end{array}$ & $\begin{array}{l}\text { Vague expectations or lack of clear expecta- } \\
\text { back is provided throughout the course. }\end{array}$ \\
\hline $\begin{array}{l}\text { Regular opportunities for self and peer as- } \\
\text { sessment in connection to course outcomes. }\end{array}$ & $\begin{array}{l}\text { Few opportunities for self and peer assess- } \\
\text { ment in connection to course outcomes. }\end{array}$ \\
\hline $\begin{array}{l}\text { Opportunities for students to co-construct } \\
\text { criteria for assignments, with the intent that } \\
\text { this will help them understand learning ex- } \\
\text { pectations of assignments. }\end{array}$ & No input into expectations for assignments. \\
\hline
\end{tabular}




\begin{tabular}{|l|l|}
\hline $\begin{array}{l}\text { Marks for assignments reflect students' } \\
\text { knowledge and skill in relation to course } \\
\text { outcomes. }\end{array}$ & $\begin{array}{l}\text { Marks for assignments are skewed by aspects } \\
\text { of student behaviour or work habits (such as } \\
\text { late submissions). }\end{array}$ \\
\hline $\begin{array}{l}\text { Opportunities to demonstrate skill and } \\
\text { knowledge through a variety of formats (in- } \\
\text { cluding visual, oral, and written). }\end{array}$ & $\begin{array}{l}\text { Overreliance on testing and no choice in for- } \\
\text { mat to demonstrate skill and knowledge. }\end{array}$ \\
\hline $\begin{array}{l}\text { When a quiz is deemed appropriate to enable } \\
\text { students to demonstrate their learning (for } \\
\text { example, assessment of factual knowledge), } \\
\text { support is offered for the process of taking } \\
\text { quizzes (such as the early introduction of test } \\
\text { procedures, provision of sample questions } \\
\text { two weeks prior to the quiz, a list identify- } \\
\begin{array}{l}\text { ing key areas to be tested, test seating plan, } \\
\text { regular reminders leading up to the quiz, and } \\
\text { reduced overall weighting of the quiz in rela- } \\
\text { tion to the final grade). }\end{array}\end{array}$ & $\begin{array}{l}\text { Supportive procedures for the administration } \\
\text { of quizzes are not clearly conveyed to stu- } \\
\text { about the purpose of the test, the kinds of test } \\
\text { questions to be encountered on the test, and/ } \\
\text { or the key areas to be tested. }\end{array}$ \\
\hline
\end{tabular}

Our understanding of a success for all philosophy informs our instructional decisions and assessment practices in how we emphasize ongoing communication and discussion about the outcomes of the course, and related assignment criteria, and in how we provide regular descriptive feedback to students as evidence of their knowledge and skill progress leading up to completion of final assignments and summative grades.

In the established literature, there is a wealth of narrative research documenting the relationship between the development of teacher knowledge and teachers' experiences in various learning situations and settings (Barak, Gidron, \& Turniansky, 2010; Carillo \& Baguley, 2011; Chan, 2006; Chang \& Rosiek 2003; Craig, 2006, 2007; Elbaz-Luwisch, 2010; Murray Orr \& Olson 2007; Olson \& Craig 2001; Shields, 2005; Vloet \& van Swet, 2010). Using a narrative conceptualization of teacher knowledge (Xu \& Connelly, 2009) enabled us to identify insights into our understanding of teaching pre-service teachers about assessment in our context.

As part of our theoretical framework, we include Joyce and Calhoun's (2010) conceptualization of horizontal and vertical transfer of new learning. Joyce and Calhoun propose that there is a significant difference between the two as "practices differ in complexity and familiarity. ... More complex and more unfamiliar ones require more concentration and energy if implementation is to occur" (p. 100). They define horizontal transfer of learning as "an easy transition from a workshop to a practice in the workplace" (p. 100) and vertical transfer as "the need for new learning by the practitioner as the new learning is implemented" (emphasis added, p. 101). The work of Joyce and Calhoun enabled us to further identify instances in which pre-service teachers struggled to understand the philosophy of success for all (Stiggins, 2005) informing our teaching and the assessment strategies 
that we model and have them experience in order to make our pedagogy and these connections explicit. Thinking of pre-service teachers' new learning in terms of horizontal and vertical transfer drew our attention to the complexity of what they were learning about assessment and to the importance of scaffolding their learning (Warford, 2011).

\section{Methodology}

Our examination of our experiences situated within the teaching of pre-service teacher assessment courses is grounded in self-study as a way to better understand the implications and possibilities of our work for future teachers (Hamilton \& Pinnegar, 2013) and as a way to improve the quality of our instructional practices (Lunenberg, Korthagen, \& Swennen, 2007). Bullough and Pinnegar (2001) describe self-study as arising from

concern about and interest in the interaction of the self-as-teacher educator, in context, over time, with others whose interests represent a shared commitment to the development and nurturance of the young and the impact of that interaction on self and other. (p. 15)

Particularly meaningful for us within this definition is Bullough and Pinnegar's emphasis upon the influence of teacher educators upon those they teach and the collaborative nature of such undertakings. As a way to think about our teaching practices and their impact upon the assessment education of our pre-service teachers, we met every two weeks in the late fall of 2012 and throughout the winter of 2013 to discuss and identify successes and challenges that happened during our classes. During these ongoing discussions we shared reflective field notes about classes and anonymous examples of pre-service teachers' work and feedback to particular activities, as well as research articles that we felt would further enrich our theoretical understanding of what we had experienced.

Emerging from our discussions was a theme that focused upon the disconnect many of our pre-service teachers seemed to be experiencing in response to our use of assessment strategies that focused upon students' learning as a process over time. Looking at these recurring moments more closely, we asked questions about the temporal, social, and contextual dimensions (Connelly \& Clandinin, 2006) informing these instances as a way to better understand their significance and how they shaped our understanding of what was being lived. Thinking narratively (Connelly \& Clandinin, 1990) about what we were living in the classroom enabled us to consider the prior learning and assessment experiences of the pre-service teachers with whom we work and the higher education context in which we are situated. Pinpointing this resonance validated the importance of our self-study and its connection to our teaching practices, and encouraged us to consider how our experiences may be relevant to other educational contexts and trends in teacher education and higher education (Bullough \& Pinnegar, 2001). The moments that are shared in this paper are representative of recurring challenges in our teaching of assessment to preservice teachers. The moments are not atypical in our teaching and reflect instances that we encounter in our experiences over time in teaching assessment courses.

In what follows we share three assessment moments and situate these moments in a discussion about the challenge of living out a philosophy of success for all in a higher education context of sort and rank. These moments represent instances that are ongoing in 
our experiences in teaching pre-service teachers about assessment. By investigating moments that resonate within and across our teaching, we are able to name bumping points that indicate the constraints shaping the context in which we teach and that enabled us to identify actions for our teaching practices.

\section{Assessment Moments}

\section{Moment 1, October 1, 2012 (Deborah Graham)}

A student entered my office, sat down, and began to share his concerns about what we had discussed in our assessment class that morning. He said that while offering descriptive feedback on work was great, what mattered most to him was the grade. As he looked into my eyes, he stated quite assertively, "Come on, Deb, the grade does matter." He went on to tell me that he had aspirations for further study and that achieving an 85 percent average was paramount to his success.

When this student left my office I was shocked; his comments took me completely off guard. As I sat there that morning attempting to reconstruct the conversation we had just had, my feelings quickly turned from shock to disappointment and frustration. I realized that our discussion in class that morning about delaying grades and instead offering descriptive feedback early on in the learning process as a way to support student learning, increase understanding, and set a student up for success seemed to mean little to him, at least within his own context as a pre-service teacher. His comments left me wondering about a lot of things, including the weight placed on grades by many students. Also, I was concerned "about the learning and transformation required to have pre-service teachers adopt assessment practices" (Munroe et al., 2012, p. 62). In other words, this conversation left me wondering if he might carry this mindset of grades into his own practice.

\section{Moment 2, October 29, 2012 (Jennifer Mitton Kukner)}

Hello Jennifer,

I just wanted to send you a quick message about the quiz this morning. I am feeling really stressed about it and do not believe I did well at all. I felt really nervous and emotional going into it, and I am stressed to the max and felt terrible about my performance afterwards. I over analyze everything and feel that I did not get to show my learning at all. I have learned so much from you, and just hope you know that. I just wanted to talk to you about it I guess, so I can put my mind at ease. My schedule is jam packed today and tomorrow, and I was wondering if Wed or Thurs you were free?

Thanks Jennifer,

S.

Upon reading this email I was filled with anxiety about returning the quizzes on Wednesday morning. I had marked the quizzes and knew that S. had achieved an $83 \%$, 
but because of her email I was still concerned that her fears went deeper than this and that she would react negatively to such an achievement.

After handing out the quizzes to the class, I walked about, taking questions and checking in with each group. While the other students at her table seemed engaged, I quietly asked S. if she would like to talk after class. She smiled and said, "No, everything is fine now. I got my quiz and the grade is great. I just get really anxious about exams." Not quite knowing what to do, I said that I was glad she was feeling better and left it at that.

\section{Moment 3, November 2, 2012 (Elizabeth Munroe)}

"Did we get in the 9os?" asked one of the two young men who entered my office. They could see that I was marking their assessment plan, a major assignment in our course. I was surprised by the question, especially since two required pieces were missing from their work. When I mentioned this, the students were shocked and visibly concerned. They indicated that they had certainly done those parts of the assignment, but somehow had not included them in their submission. They asked if they could print the missing pieces and bring them to me right away, and I agreed with no hesitation. The two students were effusive in their gratitude to me. I decided to point out what I had just done, as a teacher. "You know that I could have given you zeros for those missing parts of your assignment, but that would go against my basic philosophy of success for all, rather than sort and rank. I'm hoping that, when you are both teachers, you will do the same kind of thing for your students."

\section{Looking Across the Moments}

In our conversations about these three moments, what became apparent was the importance of grades for all involved, a realization that left the three us wondering about students' understanding of grades in relation to the assessment principles we had explicitly modelled (Hudson-Ross \& Graham, 2000; Roscoe, 2013). As demonstrated in Deb's and Jennifer's moments, the grades for these pre-service teachers had profound implications for their identity and for their understanding of themselves as learners.

In Deb's moment the student's emphasis on receiving top grades over understanding course content left her feeling discouraged. As she reflected on the class that she had taught, she wondered what had caused this student to lose sight of the goal of the class that morning: to have her students realize the significance of delaying grades and providing timely feedback instead in order to move a student forward and to ensure understanding and success instead of failure. It caused her to step back and ask questions: What exactly do grades mean to this student? Are they just a means to an end with the sole purpose of providing credentials for further study or for the labour market (Brotheridge \& Lee, 2005)? If this was the case, would he carry this mindset into his own teaching practice and consequently reduce the work of his own students to a letter or number without any further explanation?

Deb believed that she had taken considerable time in class that morning discussing the importance of offering descriptive feedback devoid of marks early in the learning process. In fact, one activity of the morning gave students an opportunity to examine samples (anonymously) of feedback that she had given to date in the course. She had invited stu- 
dents to discuss which parts of her feedback (1) indicated that progress had been made and (2) made suggestions for improvement. Her point in being so open and deliberate was to emphasize that assessment of this nature was a fair way to set them up for success, whereas a grade given too soon would have no such detail, leaving them to wonder what corrective action they might have taken. In light of the conversation following her class, she felt that her efforts were lost on this student. It was obvious that the grade was monumental and that learning the content of the course paled in comparison, a mindset that he carried with him for the remainder of the course despite her efforts.

In the case of the student in Jennifer's course, the student placed great importance upon the grade she would achieve on the test. We note the emphasis the student placed upon her effort in Jennifer's course and her seeming desire to talk further about the quiz before she learned her grade. Upon discovering that she had indeed done very well, she was no longer concerned or interested in thinking further about the quiz, the anxiety it caused her, nor the practices that Jennifer had implemented in the class to create an opportunity in which she would achieve-introduction of test procedures, provision of sample questions, a list identifying key areas to be tested, test seating plan, regular reminders leading up to the quiz, and reduced overall weighting of the quiz in relation to the final grade-leaving us to wonder which of these modelled assessment practices would remain a part of her learning.

Elizabeth's moment, we felt, illustrated two key ideas. The first is the students' expectation of success in the assignment. Their opening question not only showed their interest in obtaining high marks but also suggested the students were very confident they had done well. These particular students were not doing poorly in the course, but they were certainly not achieving marks in the 9os. Where did their confidence come from? We suggest that Elizabeth's use of various supportive assessment strategies led these students to be very secure in the quality of their assignment. Elizabeth had increased the students' potential for success by providing an exemplar of this assignment (distributed with permission from a previous year's student) and by sharing the marking scheme, with detailed criteria, as the students began their work on the assignment.

The second key idea that we note in Elizabeth's assessment moment is about grading practices that punish students' work habits, as opposed to grading practices that seek to develop a mark that reflects what the students know and can do. Punitive practices such as penalizing students for submitting late or incomplete assignments were considered to be acceptable when a school's mission was to sort and rank students. With a mission of success for all (Stiggins, 2005), teachers give increased careful attention to what students have actually learned. Students' grades should reflect their learning of the intended outcomes for the course and should not be distorted by various factors external to that focus (O'Connor, 2011). The two young men in Elizabeth's office may have had many years of experience with teachers implementing punitive assessment practices, and therefore they expected that Elizabeth would not give them a second chance, but rather would deduct marks for the incomplete parts of the assignment. Even though they had just completed 36 hours of class time during which Elizabeth had explicitly modelled assessment for learning practices, had facilitated discussions about the success for all philosophy, and had required students to read various supporting texts and documents, they apparently did not expect such practices to be applied to them. As we reflect upon this, we wonder what more can be done so that these future teachers have truly internalized a success for all philosophy. 


\section{Responding to the Challenges of Modelling Success for All in Pre-Service Teacher Education}

Upon close examination of our assessment moments and the various perspectives on grades, we noted with interest that in each of these incidents the pre-service teachers seemed to have much confidence in the meaning of a final summative grade (DeLuca \& Klinger, 2010) as communicating a representation of their learning, particularly if the grade was perceived positively. For example, we saw how Deb's student was insistent on receiving a high grade on a formative task, how Jennifer's student was content with the grade of her quiz score, and how Elizabeth's students worked hard to ensure their assignment received a high grade, which they felt reflected their efforts. Given the increasing emphasis on metacognition as significant for student learning and formative assessment practices as fostering it (Black \& Wiliam, 1998; Chappuis, 2009; Earl, 2013), we are mindful that despite our efforts to provide opportunities for our pre-service teachers to experience supportive assessment practices, some of them seemed to have more confidence in a grade than in the actual process in which they engaged over the nine-week course. The confidence they had in summative grades points to the impact of their prior learning and assessment experiences (DeLuca \& Klinger, 2010; Klinger, Volante, \& DeLuca, 2012) and also suggests that for some pre-service teachers one assessment course is not enough to shift their understanding of assessment to one that entails a success for all philosophy.

Research on pre-service teacher education and assessment points to the need to better educate pre-service teachers about assessment in a variety of ways: through explicitly modelling current instructional and assessment strategies for them while they are enrolled in assessment courses (Graham, 2005; Poth, 2013; Roscoe, 2013; Volante, 2006b; Volante \& Fazio, 2007); by encouraging them to examine their own beliefs and experiences in regard to assessment (Graham, 2005; Wang et al., 2010); by providing opportunities for them to experience assessment in new ways; and by creating opportunities for them to work alongside experienced teachers who have in-depth overall understanding of assessment and the ability to accurately and fairly interpret students' assessment results (Graham, 2005; Poth, 2013; Volante, 2006b; Wang et al., 2010). Schools and universities must also work together to ensure that pre-service teachers receive consistent and informed education on how to assess students and must offer the necessary support to allow them to hone the skills they acquire within a school setting (Poth, 2013).

In this paper we have delved into the research on assessment and pre-service teachers, and have affirmed and expanded our understandings in this realm. However, our main focus has been on how to work through the tensions and challenges of perspectives surrounding grades when working with pre-service teachers, and on having them experience assessment strategies that support their learning. In our research we found little literature documenting the challenges and pedagogical implications for teacher educators as they educate pre-service teachers about assessment. Our initial findings as part of our ongoing self-study emphasize the need for further research into the assessment education of preservice teachers and the ways it is happening within teacher education programs. At the same time, we are also mindful of the limitations of our study: methodologically, we were focused upon better understanding our own practices, and thus we relied upon our reflective field notes, artifacts from our teaching, research articles that we felt were relevant, 
and our ongoing discussions during the courses and upon their completion. This meant that for the purposes of our study we did not interview pre-service teachers about their learning in the assessment courses, nor did we follow up with them as they moved into the field for their practice teaching placement. We acknowledge that following up with preservice teachers would add further meaning to our work. Our study is not meant to make generalizations about the experiences of teacher educators teaching assessment courses, but rather to provide instances and meaning that may resonate with others teaching in higher education settings.

As outlined in this paper, we have attempted as instructors to live a philosophy of success for all despite the ongoing challenge of misunderstandings surrounding grades between ourselves and our students, further compounded by the traditional assumptions about assessment informing the context in which we teach. That being said, in our evolving understanding of how to promote a fairer and more positive mindset around assessment practices in our students, we realize that further steps could be taken. As instructors of assessment courses in a teacher education program, we intend to move forward by taking the following steps:

- Explicitly describing a success for all philosophy and distinguishing it from sort and rank (Stiggins 1999, 2005) in our courses while illustrating the competing demands these philosophies place upon learners and teachers in schools (Brookhart, 2003; Earl, 2013; Moss, 2003; Volante \& Beckett, 2011; Volante 2010).

- Creating opportunities for students to inquire into their assessment experiences using the two philosophies of success for all and sort and rank as part of their theoretical lens, so as interrogate their own assessment histories (Graham, 2005; Wang et al., 2010).

- Encouraging our pre-service teachers to consume (experience) and enact some of the strategies we have modelled in our courses (DeLuca \& Klinger, 2010; DeLuca et al., 2012; Roscoe, 2013) in their practicums and supporting them in this process as we work alongside them within this context (Graham, 2005; Poth, 2013; Stiggins, 2001; Volante, 2006b; Wang et al., 2010).

- Continuing to deepen our understanding of fair assessment and refining our teaching through further research (Swennen et al., 2008).

\section{Concluding Thoughts}

This inquiry into the experiences of three teacher educators as we taught pre-service teachers about assessment was purposeful in that we wanted not only to demonstrate how the teaching of assessment is shifting with regard to K-12 contexts and teacher education, but also to show how preparing pre-service teachers in higher education settings shaped by traditional expectations of assessment is challenging. While the conversation surrounding assessment has changed dramatically in schools, this change has not been as evident in Canadian higher education (Roscoe, 2013; Stiggins, 2005). Although a philosophy of success for all is not as evident in higher education, we note with interest recent efforts in the state of Iowa, where a mandated reform has legally obligated the faculty of the three public state universities to "create and use 'formative and summative assessments' and submit a plan for using those assessments to improve student learning" (Flaherty, 2013, para. 1). As the conversation in higher education begins to evolve to take into account as- 
sessment as part of instructional decision-making and as indicative of student learning throughout the process of learning course content, we note that challenges are ahead. We have begun to talk about the significance of rethinking the meaning of grades and assessment in teacher education and to ask for the experiences of higher education instructors to be documented, not only as evidence of a shift in thinking with regard to learning but also as a practical and pedagogical resource for those in university settings.

\section{References}

Absolum, M., Flockton, L., Hattie, J., Hipkins, R., \& Reid, I. (2009). Directions for assessment in New Zealand: Developing students' assessment capabilities. Wellington, NZ: Ministry of Education. Retrieved from http://www.voced.edu.au/content/ngv48439

Alberta Assessment Consortium. (2012). Key visual: Assessing learning in the classroom. Retrieved from http://www.aac.ab.ca/

Altbach, P. G., Reisberg, L., \& Rumbley, L. E. (2009). Trendsinglobalhigher education: Tracking an academic revolution: A report prepared for the UNESCO 2009 world conference on higher education. Paris, France: United Nations Educational, Scientific, and Cultural Organization. Retrieved from http://www.uis.unesco.org/Education/Pages/ tertiary-education.aspx

Barak, J., Gidron, A., \& Turniansky, B. (with the collaboration of Arafat, A., Friling, D., Mansur, R., Simca, M., Tuval, S., \& Weinberger, T.). (2010). 'Without stones there is no arch': A study of professional development of teacher educators as a team. Professional Development in Education, 36(1), 275-287.

Black, P., \& Wiliam, D. (1998). Inside the black box: Raising standards through classroom assessment. Phi Delta Kappan, 8o(2), 1-20.

Brookhart, S. M. (2003). Developing measurement theory for classroom assessment purposes and uses. Educational Measurement: Issues and Practices, Winter, 5-12.

Brotheridge, C., \& Lee, R. (2005). Correlates and consequences of degree purchasing among Canadian university students. Canadian Journal of Higher Education, 35(2), 71-97.

Bullough, R. V., \& Pinnegar, S. (2001). Guidelines for quality in autobiographical forms of self-study research. Educational Researcher, 3O(13), 13-21.

Campbell, C., \& Evans, J. A. (2000). Investigation of preservice teachers' classroom assessment practices during student teaching. The Journal of Educational Research, 93(6), 350-355.

Carillo, C., \& Baguley, M. (2011). From school teacher to university lecturer: Illuminating the journey from the classroom to the university for two arts educators. Teaching and Teacher Education, 27, 62-72.

Chan, E. (2006). Teacher experience of culture in curriculum. Journal of Curriculum Studies, 38(2), 161-176.

Chang, P. J., \& Rosiek, J. (2003). Anticolonialist antinomies in a biology lesson: A sonata form case study of cultural conflict in a science classroom. Curriculum Inquiry, 33(3), 252-290. 
Chappuis, J. (2009). Seven strategies of assessment for learning (1st ed.). Toronto, ON: Pearson.

Connelly, F. M., \& Clandinin, D. J. (1990). Stories of experience and narrative inquiry. Educational Researcher, 19(5), 2-14.

Connelly, F. M., \& Clandinin, D. J. (2006). Narrative inquiry. In J. L. Green, G. Camilli, \& P. Elmore (Eds.), Complementary methods for research in education (3rd ed.) (pp. 477-488). Washington, DC: American Educational Research Association.

Cooper, B., \& Cowie, B. (2010). Collaborative research for assessment for learning. Teaching and Teacher Education, 26, 979-986.

Craig, C. (2006). Why is dissemination so difficult? The nature of teacher knowledge and the spread of curriculum reform. American Educational Research Journal, 43(2), 257-293.

Craig, C. (2007). Story constellations: A narrative approach to contextualizing teachers' knowledge of school reform. Teaching and Teacher Education, 23, 173-188.

DarlingHammond, L., \& Bransford, J. (Eds.). (2005). Preparing teachers for a changing world: What teachers should learn and be able to do. San Francisco, CA: Jossey-Bass.

DeLuca, C., Chavez, T., \& Cao, C. (2013). Establishing a foundation for valid teacher judgement on student learning: The role of pre-service assessment education. Assessment in Education: Principles, Policy \& Practice, 20(1), 107-126. doi:10.1080/096959 4X.2012.668870

DeLuca, C., \& Klinger, D. A. (2010). Assessment literacy development: Identifying gaps in teacher candidates' learning. Assessment in Education: Principles, Policy \& Practice, 17(4), 419-438. doi:10.1080/0969594X.2010.516643

Duncan, R. C., \& Noonan, B. (2007). Factors affecting teachers' grading and assessment practices. The Alberta Journal of Educational Research, 53(1), 1-21.

Dweck, C. (2006). Mindset: The new psychology of success. New York, NY: Ballantine Books.

Earl, L. (2013). Assessment as learning: Using classroom assessment to maximize student learning (2nd ed.). Thousand Oaks, CA: Corwin.

Elbaz-Luwisch, F. (2010). Writing and professional learning: The uses of autobiography in graduate studies in education. Teachers and Teaching: Theory and Practice, 16(3), 307-327.

Elbow, P. (1993). Ranking, evaluating and liking: Sorting out three forms of judgment. College English, 55(2), 187-206.

Ercikan, K., \& Barclay-McKeown, S. (2007). Design and development issues in provincial large-scale assessments: Designing assessments to inform policy and practice. The Canadian Journal of Program Evaluation, 22(3), 53-71.

Flaherty, C. (2013). Assessment: It's the law [Blog post]. Inside Higher Ed. Retrieved from http://www.insidehighered.com/news/2013/07/19/iowa-state-legislators-mandate-courselevel-continuous-improvement-reporting-mixed 
Graham, P. (2005). Classroom-based assessment: Changing knowledge and practice through preservice teacher education. Teaching and Teacher Education, 21, 607-621.

Gunn, T. M., \& Hollingsworth, M. (2013). The implementation and assessment of a shared 21st century learning vision: A district-based approach. Journal of Research on Technology in Education, 45(3), 201-228.

Hamilton, M., \& Pinnegar, S. (2013). A topography of collaboration: Methodology, identity, and community in self-study of practice research. Studying Teacher Education: A Journal of Self-Study of Teacher Education Practices, 9(1), 74-89.

Hatzipanagos, S., \& Rochon, R. (2010). Introduction to the special issue: Approaches to assessment that enhance learning [Editorial]. Assessment \& Evaluation in Higher Education, 35(5), 491-492. doi:10.1080/02602938.2010.493700

Hudson-Ross, S., \& Graham, P. (2000). Going public: Making teacher educators' learning explicit as a model for preservice teachers. Teacher Education Quarterly, Fall, 5-24.

Irons, A. (2008). Enhancing learning through formative assessment and feedback. London, UK: Routledge.

Joyce, B., \& Calhoun, E. (2010). Models of professional development: A celebration of educators. Thousand Oaks, CA: Corwin.

Kelsey, K. (2006). Do grades matter? A case study of the effects of grade neutrality on adult learners. North American Colleges and Teachers of Agriculture Journal, 5O(3), $30-37$.

Klinger, D., DeLuca, C., \& Miller, T. (2008). The evolving culture of large-scale assessments in Canadian education. Canadian Journal of Educational Administration and Policy, 76. Retrieved from http://www.umanitoba.ca/publications/cjeap/articles/ klinger.html.

Klinger, D. A., Volante, L., \& DeLuca, C. (2012). Building teacher capacity within the evolving assessment culture in Canadian education. Policy Futures in Education, 10(4), 447-460.

Kohn, A. (1999). From degrading to de-grading. High School Magazine, 6(5), 38-48.

Lortie, D. C. (2002). Schoolteacher: A sociological study (2nd ed.). Chicago, IL: University of Chicago Press.

Lunenberg, M., Korthagen, F., \& Swennen, A. (2007). The teacher educator as a role model. Teaching and Teacher Education, 23(5), 586-601.

MacLellan, E. (2004). Initial knowledge states about assessment: Novice teachers' conceptualizations. Teaching and Teacher Education, 20(5), 523-535.

Manitoba Education, Citizenship \& Youth. (2006). Rethinking classroom assessment with purpose in mind: Assessment for learning, assessment as learning, and assessment of learning. Retrieved from http://www.edu.gov.mb.ca/k12/assess/wncp/

Mansell, W., James, M., \& the Assessment Reform Group. (2009). Assessment in schools: Fit for purpose? A commentary by the Teaching and Learning Research Programme. London, UK: Economic and Social Research Council, Teaching and Learning Research Programme. Retrieved from www.tlrp.org/pub/documents/assessment.pdf 
McKinney, K. (2007). Enhancing learning through the scholarship of teaching and learning: The challenges and joys of juggling. San Francisco, CA: Jossey-Bass.

McMillan, J., Hellsten, L., \& Klinger, D. (2011). Classroom assessment: Principles and practices for effective standards-based instruction. Toronto, ON: Pearson Canada.

Mellanby, J., Cortina-Borja, M., and Stein, J. (2009). Deep learning questions can help selection of high ability candidates for universities. Higher Education, 57(5), 587-608.

Mertler, C. A. (2009). Teachers' assessment knowledge and their perceptions of the impact of classroom assessment on professional development. Improving Society, 12, 101-113.

Moss, P. A. (2003). Reconceptualizing validity for classroom assessment. Educational Measurement: Issues and Practices, Winter, 13-25.

Mullen, A., Goyette, K., \& Soares, J. (2003). Who goes to graduate school? Social and academic correlates of educational continuation after college. Magazine of Theory and Sociology of Education, 76(2), 143-169.

Munroe, E., Foran, A., MacLeod, K., Graham, D., Lunney-Borden, L., \& Curry, A. (2012). Walking our talk about assessment with preservice teachers. In Education, 18(2), $53-66$.

Murray Orr, A., \& Olson, M. (2007). Transforming narrative encounters. Canadian Journal of Education, 3O(3), 819-838.

Norton, L. (2009). Assessing student learning. In H. Fry, S. Ketteridge, \& S. Marshall (Eds.), A handbook for teaching and learning in higher education: Enhancing academic practice (3rd ed.) (pp. 132-149). London, UK: Routledge.

Nova Scotia. (2012.) Kids and Learning First: A plan to help every student succeed. Halifax, NS: Province of Nova Scotia. Retrieved from novascotia.ca/kidsandlearning/ pub/KL-en.pdf

O’Connor, K. (2011). A repair kit for grading: 15 fixes for broken grades (2nd ed.). Toronto, ON: Pearson.

Olson, M., \& Craig, C. (2001). Opportunities and challenges in the development of teachers' knowledge: The development of narrative authority through knowledge communities. Teaching and Teacher Education, 17, 667-684.

Popham, W. J. (2011). Transformative assessment in action: An inside look at applying the process. Alexandria, VA: ASCD.

Poth, C. (2013). What assessment knowledge and skills do initial teacher education programs address? A Western Canadian perspective. Alberta Journal of Educational Research, 58(4), 634-656.

Remesal, A. (2011). Primary and secondary teachers' conceptions of assessment: A qualitative study. Teaching and Teacher Education, 27, 472-482.

Rhodes, T. (2012). Show me the learning: Value, accreditation, and the quality of the degree. Planning for Higher Education, 4O(3), 36-42. 
Roscoe, K. (2013). Enhancing assessment in teacher education courses. The Canadian Journal for the Scholarship of Teaching and Learning, 4(1), 1-15. doi:http://dx.doi. org/10.5206/cjsotl-rcacea.2013.1.5

Russell, T., \& Bullock, S. (2010). From talk to experience: Transforming the preservice physics methods course. Brock Education, 20(1), 19-33.

Sadler, D. R. (2010). Beyond feedback: developing student capability in complex appraisal. Assessment \& Evaluation in Higher Education, 35(5), 535-550. doi:10.1080/02602930903541015

Shields, C. (2005). Using narrative inquiry to inform and guide our (re)interpretations of lived experience. McGill Journal of Education, 4O(1), 179-188.

Stiggins, R. (1999). Evaluating classroom assessment training in teacher education programs. Educational Measurement: Issues and Practice, Spring, 23-27.

Stiggins, R. (2005). From formative assessment to assessment for learning: A path to success in standards-based schools. The Phi Delta Kappan, 87(4), 324-328.

Swennen, A., Lunenberg, M., \& Korthagen, F. (2008). Preach what you teach! Teacher educators and congruent teaching. Teachers and Teaching, 14(5), 531-542.

Swift, S. A., Moore, D. A., Sharek, Z. S., \& Gino, F. (2013). Inflated applicants: Attribution errors in performance evaluation by professionals. PLOS ONE, 8(7): e69258. doi:10.1371/journal.pone.0069258.

Vickers, J. M. (2000). Justice and truth in grades and their averages. Research in Higher Education, 41(2), 141-164.

Vloet, K., \& van Swet, J. (2010). 'I can only learn in dialogue!' Exploring professional identities in teacher education. Professional Development in Education, 36(1), 149-168.

Volante, L. (2006a). An alternative vision for large-scale assessment in Canada. Journal of Teaching and Learning, 4(1), 1-14.

Volante, L. (2006b). Essential elements in teacher education: Preservice student perspectives. Alberta Journal of Educational Research, 52, 167-180. Retrieved from http://ajer.synergiesprairies.ca/

Volante, L. (2010). Assessment of, for, and as learning within schools: Implications for transforming classroom practice. Action in Teacher Education, 31(4), 66-75.

Volante, L., \& Beckett, D. (2011). Formative assessment and the contemporary classroom: Synergies and tensions between research and practice. Canadian Journal of Education, 34(2), 239-255.

Volante, L., \& Fazio, X. (2007). Exploring teacher candidates' assessment literacy: Implications for teacher education reform and professional development. Canadian Journal of Education, 30(3), 749-770.

Wang, J., Kao, H., \& Lin, S. (2010). Preservice teachers' initial conceptions about assessment of science learning: The coherence with their views of learning science. Teaching and Teacher Education, 26(3), 522-529. 
Warford, M. (2011). The zone of proximal teacher development. Teaching and Teacher Education, 27, 252-258.

White, E. (2011). Working towards explicit modeling: experiences of a new teacher educator. Professional Development in Education, 37(4), 483-497. doi:10.1080 /19415257.2010.531628

Wiliam, D. (2011). Embedded formative assessment. Bloomington, IN: Solution Tree Press.

Wiliam, D., \& Reay, D. (1999). 'I'll be a nothing': Structure, agency and the construction of identity through assessment. British Educational Research Journal 25 (3), 343-354.

Wilson, N. S. (2008). Teachers expanding pedagogical content knowledge: Learning about formative assessment together. Journal of In-Service Education, 34(3), 283- 298. doi:10.1080/13674580802003540

Xu, S., \& Connelly, F. M. (2009). Narrative inquiry for teacher education and development: Focus on English as a foreign language in China. Teaching and Teacher Education, 25, 219-227.

\section{Contact information}

Jennifer Mitton-Kukner

Faculty of Education

St. Francis Xavier University

jmitton@stfx.ca

Jennifer Mitton-Kukner is an assistant professor of assessment, literacy, and qualitative research methods in the Faculty of Education at St. Francis Xavier University in Nova Scotia. Her research interests include multiliteracies in the content areas, classroom assessment, pre-service teachers and the LGBTQ community in schools, and teachers as researchers.

Elizabeth Munroe is an assistant professor in the Faculty of Education at St. Francis Xavier University, where she teaches courses called Principles and Practices of Teaching Elementary School, and Classroom Assessment and Evaluation for the Elementary School at the BEd level, and courses related to school improvement and leadership at the MEd level. Her research interests include the professional learning of pre-service and inservice teachers, 21st-century learning, and school improvement.

Deborah Graham is an assistant professor in the Faculty of Education at St. Francis Xavier University, where she teaches courses in principles and practices of teaching, literacy, and assessment at the BEd level, and program development and various other courses at the ME level. Before joining the faculty at StFX she was a public school teacher and regional administrator for 30 years. Her research interests include middle school pedagogy, 21st-century learning, and teacher identity. 